\title{
A New Kind of Renewable Energy: Production of Aromatic Hydrocarbons Naphtha Chemical by Thermal Degradation of Polystyrene (PS) Waste Plastic
}

\author{
Moinuddin Sarker*, Mohammad Mamunor Rashid, \\ Muhammad Sadikur Rahman, Mohammed Molla \\ Natural State Research, Inc., Department of Research and Development, Stamford, USA \\ Email: ${ }^{*}$ msarker@naturalstateresearch.com
}

Received June 5, 2012; revised July 8, 2012; accepted July 20, 2012

\begin{abstract}
Polystyrene (PS) waste plastic to renewable energy or naphtha grade fuel production through fractional distillation process was applied and PS liquefaction temperature range was $250^{\circ} \mathrm{C}-430^{\circ} \mathrm{C}$ and fractional column temperature was $110^{\circ} \mathrm{C}-135^{\circ} \mathrm{C}$ for naphtha grade fuel separation. The thermal degradation of PS waste plastic to renewable energy or naphtha grade chemical production was without adding any kind of cracking catalyst and without vacuum system. Polystyrene waste plastic is not bio-degradable and its can remain long period of landfill and creating gas emission for that reason its major cause climate change. For experimental purpose raw sample was use $1 \mathrm{~kg}$ of PS waste plastic and experiment was performed under Labconco fume hood and experiment was fully closed system, whole experiment was performed into stainless steel reactor. Produced fuel was analysis by gas chromatography and mass spectrometer, FT-IR and DSC. Analysis result indicate for fuel compounds chemical structure, compound band energy and enthalpy, delta $\mathrm{H}$ value. Produced fuel sulfur content less then environmental protection agency (EPA) level and fuel could be use for chemical feedstock refinery for further modification. By using this technology can reduce some foreign oil dependency and boost up renewable energy sector all over the world.
\end{abstract}

Keywords: Renewable Energy; Climate Change; Polystyrene; Aromatic; Naphtha; Waste Plastic; Thermal Degradation; GC/MS

\section{Introduction}

The thermal pyrolysis of plastic wastes produces a broad distribution of hydrocarbons, from methane to waxy products. This process takes place at high temperatures. The gaseous compounds generated can be burned out to provide the process heat requirements, but the overall yield of valuable gasoline range hydrocarbons is poor, so that the pyrolysis process as a means for feedstock recycling of the plastic waste stream is rarely practiced on an industrial scale at present [1,2]. In contrast, thermal cracking at low temperatures is usually aimed at the production of waxy oil fractions, which may be used in industrial units for steam cracking and in fluid catalytic cracking units [3]. An alternative to improve gasoline yield from plastics pyrolysis is to introduce suitable catalysts. High conversions and interesting product distributions are obtained when plastics are cracked over zeolites [4-6]. Moreover the catalytic cracking of poly-

"Corresponding author. mers has proven itself to be a very versatile process, since a variety of products can be obtained depending on the catalyst [7-10] the polymer $[11,12]$ the reactor type $[13,14]$ and the experimental conditions used [15-17] among other variables. Currently, production of bio-fuels, including ethanol and biodiesel, primarily relies on corn and soybeans. However, demand for farm crops as fuel sources has detrimental effects including fluctuations in grain prices [18]. As alternatives to farm crops, plastic waste and waste lube oil are potentially important sources in renewable fuel and energy production [19-22].

For example, in the United States, 25 million tons of plastic wastes were discharged in 2001, and less than $4 \%$ of the plastic waste was recycled [23]. In Western Europe, 48.3 million tons of plastic solid wastes (PSW) were consumed in 2007 , and up to $60 \%$ of the plastic waste was land-filled or discharged without any treatment [24]. To date, an appropriate market for treating PSW, discharged as various types of mixtures, has not been well developed. Application of thermal techniques, 
such as gasification processes [25], pyrolytic processes [26,27], and liquid-gas hydrogenation [28], is a potentially productive approach for producing fuel by utilizing plastic waste and waste lube oil as feedstock. Plastic waste and waste lube oil have high heat capacities (e.g., polyolefins: $\sim 43.3 \mathrm{MJ} / \mathrm{kg}$ and general waste lube oil: $\sim 43.1 \mathrm{MJ} / \mathrm{kg}$ ) [29], and their heat capacities are closer to petro-diesel ( $\sim 43 \mathrm{MJ} / \mathrm{kg}$ ) [30]. However, the main problem with these wastes is that they are randomly discharged as various types of mixtures, and the physical properties and thermal degradation properties of each waste are different $[31,32]$. Thus, in the case of a mixture used as feedstock of fuel production, its efficacy has to be determined mainly by the ratio of the mixed plastic waste and waste lube oil, taking into account their physio-chemical interactions. Several researchers have studied the feasibility of producing fuel from a mixture of plastic waste and waste oil treated through thermolysis, focusing in particular on analysis of regenerated-fuel quality [33] and evaluation of thermal reaction conditions [34]. However, fundamental questions that have not been discussed are the physio-chemical interactions of the waste mixture and their effect on energy consumption and thermodynamic parameters during thermolysis [35]. About $16 \%$ of global final energy consumption comes from renewables, with $10 \%$ coming from traditional biomass, which is mainly used for heating, and 3.4\% from hydroelectricity. New renewables (small hydro, modern biomass, wind, solar, geothermal, and biofuels) accounted for another $3 \%$ and are growing very rapidly [36]. The share of renewables in electricity generation is around $19 \%$, with $16 \%$ of global electricity coming from hydroelectricity and 3\% from new renewables [36].
GHG emissions associated with the provision of energy services are a major cause of climate change. The AR4 concluded that "Most of the observed increase in global average temperature since the mid-20th century is very likely due to the observed increase in anthropogenic greenhouse gas concentrations" (IPCC, 2007a). Concentrations of $\mathrm{CO}_{2}$ have continued to grow since the AR4 to about $390 \mathrm{ppm} \mathrm{CO}_{2}$ or $39 \%$ above pre-industrial levels by the end of 2010 (IPCC, 2007b; NOAA, 2010). The global average temperature has increased by $0.76^{\circ} \mathrm{C}$ $\left(0.57^{\circ} \mathrm{C}\right.$ to $\left.0.95^{\circ} \mathrm{C}\right)$ between 1850 to 1899 and 2001 to 2005 , and the warming trend has increased significantly over the last 50 years (IPCC, 2007b). While this report focuses on the energy sector, forest clearing and burning and land use change, and the release of non- $\mathrm{CO}_{2}$ gases from industry, commerce and agriculture also contribute to global warming (IPCC, 2007b) [37] and some other researcher journal was cited for climate change [38-40].

\section{Experimental Section}

Polystyrene (PS) waste plastic was collected from local city grocery store and it was drinking coffee glass. Collected coffee glass cleaned with liquid soap and water. PS waste plastic were cut into small pieces and size was $1-2$ inch $^{2}$. Small pieces PS waste plastic put into reactor chamber and rector chamber was made by 316 grade stainless steel. Reactor temperature capability up $500^{\circ} \mathrm{C}$ and temperature controller purposed used watlow device. PS waste plastic and reactor chamber was placed inside reactor and covered with screw tighten and top on cover placed one fractional distillation column with different temperature profiles Figure 1). In this experiment main

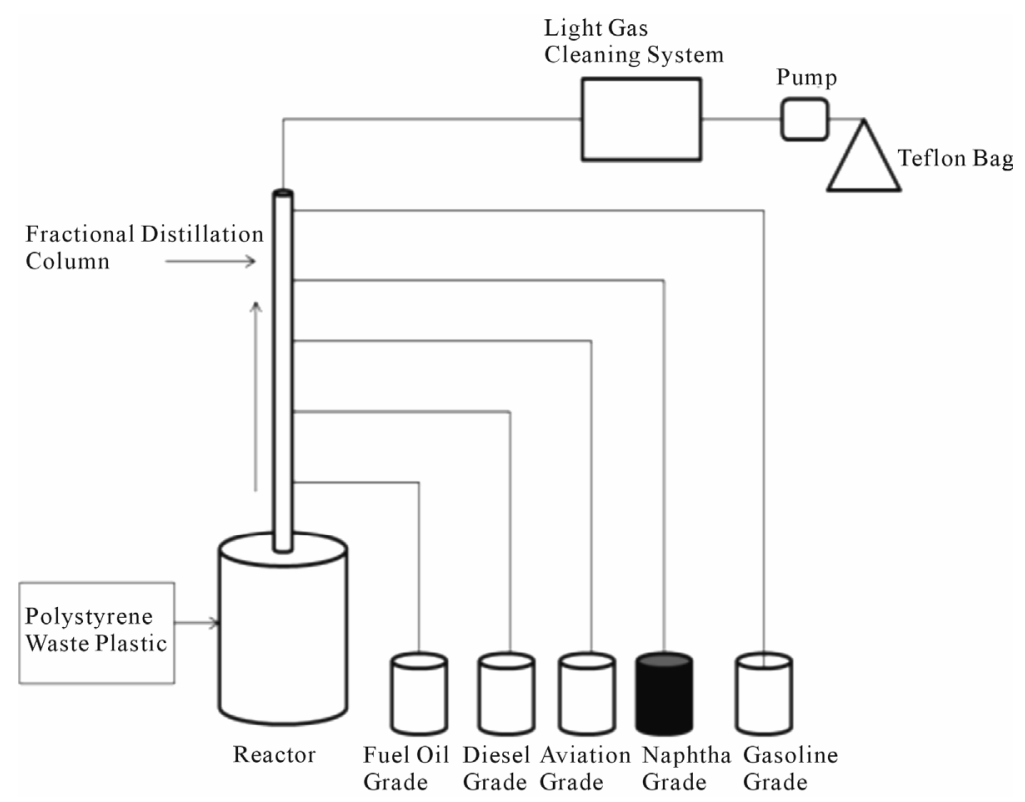

Figure 1. Polystyrene waste plastic to naphtha grade fuel production process. 
goal was naphtha fraction chemical collection. First reactor chamber was heated up $250^{\circ} \mathrm{C}$ to PS liquefaction purpose and fractional column was used for fraction grade fuel collection. Reactor temperature initial heating temperature was $250^{\circ} \mathrm{C}$ and from this temperature increased gradually step by step at $15^{\circ} \mathrm{C}$ every 10 minutes interval up to $430^{\circ} \mathrm{C}$. Due to temperature increase PS waste plastic melted then turn into liquid at the end solid plastic turn vapor formation when temperature cross up to $350^{\circ} \mathrm{C}$. From $350^{\circ} \mathrm{C}$ to $430^{\circ} \mathrm{C}$ temperature experiment was run constantly until finished the experiment. Fractional distillation process we can collect different grade fuel and from this experiment we collected naphtha grade chemical and also other grade fuel. For Naphtha grade chemical collection fractional distillation column temperature was setup $110^{\circ} \mathrm{C}-135^{\circ} \mathrm{C} .1 \mathrm{~kg}$ of PS waste plastic was use for the experiment. In the experiment PS waste plastic to naphtha grade chemical collection period some light gas also collected. These types of light gas have negative boiling point and mixture of methane, ethane, propane and butane. These gases passed through the alkali solution and remove contamination and transfer into Teflon bag for future use. This light gas could be use as heat source for PS waste plastic to fuel production purposes. Experiment was fully close system and vacuum system was not applied. In this experiment catalyst and chemical did not applied only thermal process used. Collected naphtha grade fuel or chemical was purification by using RCI purification technology for removing ash, water or fuel sediment. Collected fuel density is 0.87 $\mathrm{gm} / \mathrm{ml}$. From the experiment mass balance calculation percentage showed naphtha grade chemical yield percentage is $21 \%$ and rest of other grade fuel was $66 \%$, light gas yield percentage was $5 \%$ and solid black residue percentage was $8 \%$. Produced residue has good Btu value up to 5000 per pound. For experimental purpose $1 \mathrm{~kg}$ PS waste plastic to naphtha grade chemical production including other grade fuel used electricity is $6.66 \mathrm{kWh}$ and conversion time was 5 - 6 hours.

\section{Results and Discussion}

From Perkin Elmer GC-MS analysis of polystyrene (PS) plastic to aromatic naphtha grade chemical (Figure 2 and Table 1) in accordance with the various retention times and trace masses different types of hydrocarbon compound and benzene derivatives compounds are appeared in the analysis result index. Many compounds are emerged on the analysis carbon range $C_{7}$ to $C_{16}$. Based on the retention time and trace mass following hydrocarbon compounds as follows such as at the initial phase of the analysis at retention time 4.85 and trace mass 91 , compound is Toluene $\left(\mathrm{C}_{7} \mathrm{H}_{8}\right)$, retention time 5.30 and trace mass 43 , compound is Hexane, 3-ethyl- $\left(\mathrm{C}_{8} \mathrm{H}_{18}\right)$,

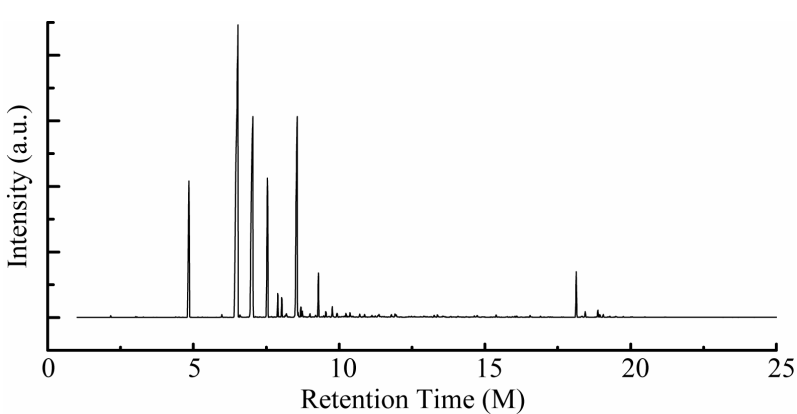

Figure 2. GC/MS Chromatogram of polystyrene waste plastic to naphtha fractional fuel.

retention time 5.97 and trace mass 54, compound is Cyclohexane, 4-ethenyl- $\left(\mathrm{C}_{8} \mathrm{H}_{12}\right)$, retention time 6.52 and trace mass 106 , compound is 3,5 -Octadiyne $\left(\mathrm{C}_{8} \mathrm{H}_{10}\right)$, retention time 7.04 and trace mass 51 , compound is $1,3,5,7-$ Cyclooctatetraene $\left(\mathrm{C}_{8} \mathrm{H}_{8}\right)$, retention time 7.54 and trace mass 120 , compound is 1-Hexen-4-yne, 3-ethylidene-2methyl- $\left(\mathrm{C}_{9} \mathrm{H}_{12}\right)$, retention time 7.89 and trace mass 117 , compound is Benzene, 2-propenyl- $\left(\mathrm{C}_{9} \mathrm{H}_{10}\right)$, retention time 8.03 and trace mass 91, compound is Benzene, propyl$\left(\mathrm{C}_{9} \mathrm{H}_{12}\right)$, retention time 8.56 and trace mass 118 , compound is $\alpha$-Methylstyrene $\left(\mathrm{C}_{9} \mathrm{H}_{10}\right)$ retention time 8.74 and trace mass 57 , compound is Decane $\left(\mathrm{C}_{10} \mathrm{H}_{22}\right)$, retention time 9.93 and trace mass 105 , compound name is Benzene, 1-ethyl-4-methyl- $\left(\mathrm{C}_{9} \mathrm{H}_{12}\right)$, retention time 10.13 and trace mass 41, compound name is Hexane, Isopinocarveol- $\left(\mathrm{C}_{10} \mathrm{H}_{16} \mathrm{O}\right)$, retention time 10.30 and trace mass 117 , compound is Benzene,4-ethenyl-1,2-dimethyl- $\left(\mathrm{C}_{10} \mathrm{H}_{12}\right)$, retention time 11.12 and trace mass 118 , compound is Benzene, (1-ethyl-2-propenyl)- $\left(\mathrm{C}_{11} \mathrm{H}_{14}\right)$, retention time 11.33 and trace mass 91, compound is Cyclohexene, 3-methylene-4-(1,2-propadienyl)- $\left(\mathrm{C}_{10} \mathrm{H}_{112}\right)$, retention time 11.79 and trace mass 91, compound is Benzene, pentyl- $\left(\mathrm{C}_{11} \mathrm{H}_{16}\right)$, retention time 12.48 and trace mass 91 compound is Benzene, cycloppentyl- $\left(\mathrm{C}_{11} \mathrm{H}_{14}\right)$, retention time 13.37 and trace mass 48 , compound is Tetradecane, $\left(\mathrm{C}_{14} \mathrm{H}_{30}\right)$, retention time 14.64 and trace mass 41 , compound is 7-Tetradecene, $\left(\mathrm{C}_{14} \mathrm{H}_{28}\right)$, retention time 15.38 and trace mass 167, compound is Benzene, 1,1'-ethylidenebis- $\left(\mathrm{C}_{14} \mathrm{H}_{24}\right)$. Also at retention time 16.55 and trace mass 91, compound is Benzene, 1,1 '-(1,2-ethanediyl)bis- $\left(\mathrm{C}_{14} \mathrm{H}_{14}\right)$, retention time 16.91 and trace mass 105 functional group is Benzene, 1,1'-(1-methyl-1,2-ethanediyl)bis- $\left(\mathrm{C}_{15} \mathrm{H}_{16}\right)$, retention time 18.44 and trace mass 105 , compound is Benzene, 1,1'-(1-methyl-1,3-propanediyl)bis- $\left(\mathrm{C}_{16} \mathrm{H}_{18}\right)$ etc. In the ultimate phase of the analysis index several compound are detected as according to their retention time and trace masses such as retention time 18.14 and trace mass 92, functional group is Benzene group compound Benzene, 1,1'-(1,3-propanediyl)bis- $\left(\mathrm{C}_{15} \mathrm{H}_{16}\right)$, retention time 18.44 and trace mass 105 , compound is a Benzene, 
Table 1. GC/MS Chromatogram of polystyrene waste plastic to naphtha fractional fuel compound list.

\begin{tabular}{|c|c|c|c|c|c|c|}
\hline $\begin{array}{l}\text { Number of } \\
\text { peak }\end{array}$ & $\begin{array}{l}\text { Retention time } \\
\text { (M) }\end{array}$ & $\begin{array}{l}\text { Trace mass } \\
(\mathbf{m} / \mathbf{z})\end{array}$ & Compound name & $\begin{array}{l}\text { Compound } \\
\text { formula }\end{array}$ & $\begin{array}{l}\text { Molecular } \\
\text { weight }\end{array}$ & Probability \% \\
\hline 1 & 4.85 & 91 & Toluene & $\mathrm{C}_{7} \mathrm{H}_{8}$ & 92 & 30.9 \\
\hline 2 & 5.30 & 43 & Hexane, 3-ethyl- & $\mathrm{C}_{8} \mathrm{H}_{18}$ & 114 & 35.3 \\
\hline 3 & 5.97 & 54 & Cyclohexene, 4-ethenyl- & $\mathrm{C}_{8} \mathrm{H}_{12}$ & 108 & 35.6 \\
\hline 4 & 6.52 & 106 & 3,5-Octadiyne & $\mathrm{C}_{8} \mathrm{H}_{10}$ & 106 & 30.3 \\
\hline 5 & 7.02 & 50 & 1,3,5,7-Cyclooctatetraene & $\mathrm{C}_{8} \mathrm{H}_{8}$ & 104 & 36.0 \\
\hline 6 & 7.04 & 51 & 1,3,5,7-Cyclooctatetraene & $\mathrm{C}_{8} \mathrm{H}_{8}$ & 104 & 30.0 \\
\hline 7 & 7.54 & 120 & 1-Hexen-4-yne, 3-ethylidene-2-methyl- & $\mathrm{C}_{9} \mathrm{H}_{12}$ & 120 & 18.7 \\
\hline 8 & 7.89 & 117 & Benzene, 2-propenyl- & $\mathrm{C}_{9} \mathrm{H}_{10}$ & 118 & 17.1 \\
\hline 9 & 8.03 & 91 & Benzene, propyl- & $\mathrm{C}_{9} \mathrm{H}_{12}$ & 120 & 82.1 \\
\hline 10 & 8.56 & 118 & $\alpha$-Methylstyrene & $\mathrm{C}_{9} \mathrm{H}_{10}$ & 118 & 15.9 \\
\hline 11 & 8.69 & 117 & Benzene, 2-propenyl- & $\mathrm{C}_{9} \mathrm{H}_{10}$ & 118 & 18.1 \\
\hline 12 & 8.74 & 57 & Decane & $\mathrm{C}_{10} \mathrm{H}_{22}$ & 142 & 30.5 \\
\hline 13 & 9.29 & 117 & Benzene, 2-propenyl- & $\mathrm{C}_{9} \mathrm{H}_{10}$ & 118 & 29.2 \\
\hline 14 & 9.54 & 91 & Benzene, 3-butenyl- & $\mathrm{C}_{10} \mathrm{H}_{12}$ & 132 & 81.4 \\
\hline 15 & 9.76 & 91 & $1,2,3,4,5,8$-Hexahydronaphthalene & $\mathrm{C}_{10} \mathrm{H}_{14}$ & 134 & 27.9 \\
\hline 16 & 9.93 & 105 & Benzene, 1-ethyl-4-methyl- & $\mathrm{C}_{9} \mathrm{H}_{12}$ & 120 & 11.9 \\
\hline 17 & 10.1 & 106 & $\begin{array}{l}\text { 3a,6-Methano-3aH-inden-4-ol, } \\
\text { octahydro-, }(3 \mathrm{a} \alpha, 4 \alpha, 6 \alpha, 7 \mathrm{a} \beta) \text { - }\end{array}$ & $\mathrm{C}_{10} \mathrm{H}_{16} \mathrm{O}$ & 152 & 13.0 \\
\hline 18 & 10.13 & 41 & Isopinocarveol & $\mathrm{C}_{10} \mathrm{H}_{16} \mathrm{O}$ & 152 & 17.3 \\
\hline 19 & 10.18 & 117 & Benzene, 2-butenyl- & $\mathrm{C}_{10} \mathrm{H}_{12}$ & 132 & 16.2 \\
\hline 20 & 10.24 & 41 & 3-Undecene, (E)- & $\mathrm{C}_{11} \mathrm{H}_{22}$ & 154 & 9.33 \\
\hline 21 & 10.30 & 117 & Benzene, 4-ethenyl-1,2-dimethyl- & $\mathrm{C}_{10} \mathrm{H}_{12}$ & 132 & 9.28 \\
\hline 22 & 10.37 & 43 & Undecane & $\mathrm{C}_{11} \mathrm{H}_{24}$ & 156 & 35.5 \\
\hline 23 & 10.47 & 105 & Benzene, (1-methylbutyl)- & $\mathrm{C}_{11} \mathrm{H}_{16}$ & 148 & 18.3 \\
\hline 24 & 10.60 & 41 & 2-Decyn-1-ol & $\mathrm{C}_{10} \mathrm{H}_{18} \mathrm{O}$ & 154 & 8.85 \\
\hline 25 & 10.71 & 117 & Benzene, (2-methyl-1-propenyl)- & $\mathrm{C}_{10} \mathrm{H}_{12}$ & 132 & 11.4 \\
\hline 26 & 10.83 & 92 & 5,7-Dodecadiyn-1,12-diol & $\mathrm{C}_{12} \mathrm{H}_{18} \mathrm{O}_{2}$ & 194 & 10.9 \\
\hline 27 & 10.88 & 117 & Benzene, 1-butenyl-, (E)- & $\mathrm{C}_{10} \mathrm{H}_{12}$ & 132 & 18.5 \\
\hline 28 & 10.93 & 41 & Z,Z,Z-1,4,6,9-Nonadecatetraene & $\mathrm{C}_{19} \mathrm{H}_{32}$ & 260 & 6.33 \\
\hline 29 & 11.12 & 118 & Benzene, (1-ethyl-2-propenyl)- & $\mathrm{C}_{11} \mathrm{H}_{14}$ & 146 & 37.7 \\
\hline 30 & 11.24 & 104 & Benzene, 4-pentenyl- & $\mathrm{C}_{11} \mathrm{H}_{14}$ & 146 & 50.1 \\
\hline 31 & 11.33 & 91 & $\begin{array}{c}\text { Cyclohexene, } \\
\text { 3-methylene-4-(1,2-propadienyl)- }\end{array}$ & $\mathrm{C}_{10} \mathrm{H}_{12}$ & 132 & 23.06 \\
\hline 32 & 11.36 & 91 & Benzene, pentyl- & $\mathrm{C}_{11} \mathrm{H}_{16}$ & 148 & 63.03 \\
\hline 33 & 11.79 & 41 & 3-Dodecene, (E)- & $\mathrm{C}_{12} \mathrm{H}_{24}$ & 168 & 15.05 \\
\hline 34 & 11.91 & 43 & Dodecane & $\mathrm{C}_{12} \mathrm{H}_{26}$ & 170 & 12.0 \\
\hline
\end{tabular}


Continued

\begin{tabular}{|c|c|c|c|c|c|c|}
\hline 35 & 12.48 & 91 & Benzene, cyclopentyl- & $\mathrm{C}_{11} \mathrm{H}_{14}$ & 146 & 18.9 \\
\hline 36 & 12.91 & 91 & Benzene, hexyl- & $\mathrm{C}_{12} \mathrm{H}_{18}$ & 162 & 37.0 \\
\hline 37 & 13.37 & 48 & Tetradecane & $\mathrm{C}_{14} \mathrm{H}_{30}$ & 198 & 11.8 \\
\hline 38 & 14.64 & 41 & 7-Tetradecene & $\mathrm{C}_{14} \mathrm{H}_{28}$ & 196 & 5.75 \\
\hline 39 & 15.38 & 167 & Diphenylmethane & $\mathrm{C}_{13} \mathrm{H}_{12}$ & 168 & 56.5 \\
\hline 40 & 16.09 & 167 & Benzene, 1,1'-ethylidenebis- & $\mathrm{C}_{14} \mathrm{H}_{14}$ & 182 & 35.0 \\
\hline 41 & 16.55 & 91 & Benzene, 1,1'-(1,2-ethanediyl)bis- & $\mathrm{C}_{14} \mathrm{H}_{14}$ & 182 & 71.7 \\
\hline 42 & 16.91 & 105 & $\begin{array}{c}\text { Benzene, } \\
1,1 \text { '-(1-methyl-1,2-ethanediyl)bis- }\end{array}$ & $\mathrm{C}_{15} \mathrm{H}_{16}$ & 196 & 42.4 \\
\hline 43 & 18.14 & 92 & Benzene, 1,1'-(1,3-propanediyl)bis- & $\mathrm{C}_{15} \mathrm{H}_{16}$ & 196 & 88.8 \\
\hline 44 & 18.44 & 105 & $\begin{array}{c}\text { Benzene, } \\
1,1^{\prime} \text {-(1-methyl-1,3-propanediyl)bis- }\end{array}$ & $\mathrm{C}_{16} \mathrm{H}_{18}$ & 210 & 58.1 \\
\hline 45 & 18.88 & 91 & Naphthalene, 1,2,3,4-tetrahydro-2-phenyl- & $\mathrm{C}_{16} \mathrm{H}_{16}$ & 208 & 27.08 \\
\hline 46 & 19.06 & 115 & 1,2-Diphenylcyclopropane & $\mathrm{C}_{15} \mathrm{H}_{14}$ & 194 & 58.6 \\
\hline 47 & 19.28 & 91 & Benzene, 1,1'-(1,4-butanediyl)bis- & $\mathrm{C}_{16} \mathrm{H}_{18}$ & 210 & 78.9 \\
\hline 48 & 19.49 & 44 & Naphthalene, 1,2,3,4-tetrahydro-1-phenyl- & $\mathrm{C}_{16} \mathrm{H}_{16}$ & 208 & 32.1 \\
\hline 49 & 19.74 & 44 & Benzene, 1,1'-(1-butenylidene)bis- & $\mathrm{C}_{16} \mathrm{H}_{16}$ & 208 & 34.0 \\
\hline
\end{tabular}

1,1'-(1-methyl-1,3-propanediyl)bis- $\left(\mathrm{C}_{16} \mathrm{H}_{18}\right)$, retention time 18.88 and trace mass 91 , compound is Naphthalene, 1,2,3,4tetrahydro-2-phenyl- $\left(\mathrm{C}_{16} \mathrm{H}_{16}\right)$, retention time 19.06 and trace mass 115 , compound is 1,2-Diphenylcyclopropane$\left(\mathrm{C}_{15} \mathrm{H}_{14}\right)$, retention time 19.28 and trace mass 91 , compound is Benzene, 1,1'-(1,4-butanediyl)bis- $\left(\mathrm{C}_{16} \mathrm{H}_{18}\right)$, and ultimately retention time 19.74 and retention time 44 , compound is Benzene, 1,1'-(1-butenylidene)bis- $\left(\mathrm{C}_{16} \mathrm{H}_{16}\right)$ respectively.

FT-IR (spectrum 100) analysis of Polystyrene (PS) waste plastic to aromatic naphtha fractional fuel (Figure 3 and Table 2) according to their wave number and spectrum band following types of functional groups are appeared in the analysis. In the spectrum field we noticed that higher wave number are emerged in the initial phase and middle index of the spectrum and in higher wave number small and bulky both functional groups are available and in low wave number double bond and single bond functional groups are available such as methane group, cis and trans alkene etc. Hereafter wave number $3619.76 \mathrm{~cm}^{-1}$, functional group is Free $\mathrm{OH}$ (Sharp), wave number $3621.23 \mathrm{~cm}^{-1}$ functional group is, Intermolecular $\mathrm{H}$ bonds, wave number $2986.91 \mathrm{~cm}^{-1}$ and $2732.43 \mathrm{~cm}^{-1}$ functional group is $\mathrm{C}-\mathrm{CH}_{3}$, wave number $2185.54 \mathrm{~cm}^{-1}$ and $2163.53 \mathrm{~cm}^{-1}$ functional group is $\mathrm{C}-\mathrm{C}=-\mathrm{C}-\mathrm{C}=-\mathrm{CH}$, wave number $1868.36 \mathrm{~cm}^{-1}, 1801.98 \mathrm{~cm}^{-1}, 1744.39 \mathrm{~cm}^{-1}$, $1705.85 \mathrm{~cm}^{-1}, 1630.00 \mathrm{~cm}^{-1}$ and $1603.97 \mathrm{~cm}^{-1}$ functional group is non-conjugated, wave number $1458.00 \mathrm{~cm}^{-1}$ and $1376.22 \mathrm{~cm}^{-1}$ functional group is $\mathrm{CH}_{3}$, wave number $1028.47 \mathrm{~cm}^{-1}$ functional group is Acetates, wave number $992.91 \mathrm{~cm}^{-1}$ functional group is $\mathrm{C}=\mathrm{CH}_{2}$ and ultimately wave number $906.99 \mathrm{~cm}^{-1}$ functional group is $\mathrm{C}=\mathrm{CH}_{2}$ etc. Energy values are calculated, using formula is $\mathrm{E}=$ $\mathrm{h} v$, Where $\mathrm{h}=$ Planks Constant, $\mathrm{h}=6.626 \times 10^{-34} \mathrm{~J}, v=$ Frequency in Hertz $\left(\mathrm{sec}^{-1}\right)$, Where $v=\mathrm{c} / \lambda, \mathrm{c}=$ Speed of light, where, $\mathrm{c}=3 \times 10^{10} \mathrm{~m} / \mathrm{s}, \mathrm{W}=1 / \lambda$, where $\lambda$ is wave length and $\mathrm{W}$ is wave number in $\mathrm{cm}^{-1}$. Therefore the equation $\mathrm{E}=\mathrm{h} v$, can substitute by the following equation, $\mathrm{E}=\mathrm{hcW}$. According to their wave number several energy values are calculated such as for $2986.91\left(\mathrm{~cm}^{-1}\right)$ calculated energy, $E=5.93 \times 10^{-20} \mathrm{~J}$. Similarly, wave number $1868.36\left(\mathrm{~cm}^{-1}\right)$ energy, $\mathrm{E}=3.71 \times 10^{-20} \mathrm{~J}$, wave number $1376.22\left(\mathrm{~cm}^{-1}\right)$ energy, $\mathrm{E}=2.73 \times 10^{-20} \mathrm{~J}$ and eventually wave number $906.99\left(\mathrm{~cm}^{-1}\right)$ functional group is $1.80 \times 10^{-20} \mathrm{~J}$ respectively.

Polystyrene waste plastic to aromatic group related naphtha fraction fuel (Figure 4) was analysis by DSC and results obtain from analysis naphtha fraction fuel graph such as onset temperature is $131.25^{\circ} \mathrm{C}$ and fuel peak temperature is $155.64^{\circ} \mathrm{C}$. Peak height is $117.1115 \mathrm{~mW}$ and fuel heat enthalpy delta $\mathrm{H}$ value is $22234.5113 \mathrm{~J} / \mathrm{g}$. Heat value area is $22234.511 \mathrm{~mJ}$ and peak end temperature is $165.85^{\circ} \mathrm{C}$. Peak $155.64^{\circ} \mathrm{C}$ is representing fuel boiling point temperature. Naphtha fractional fuel compound 


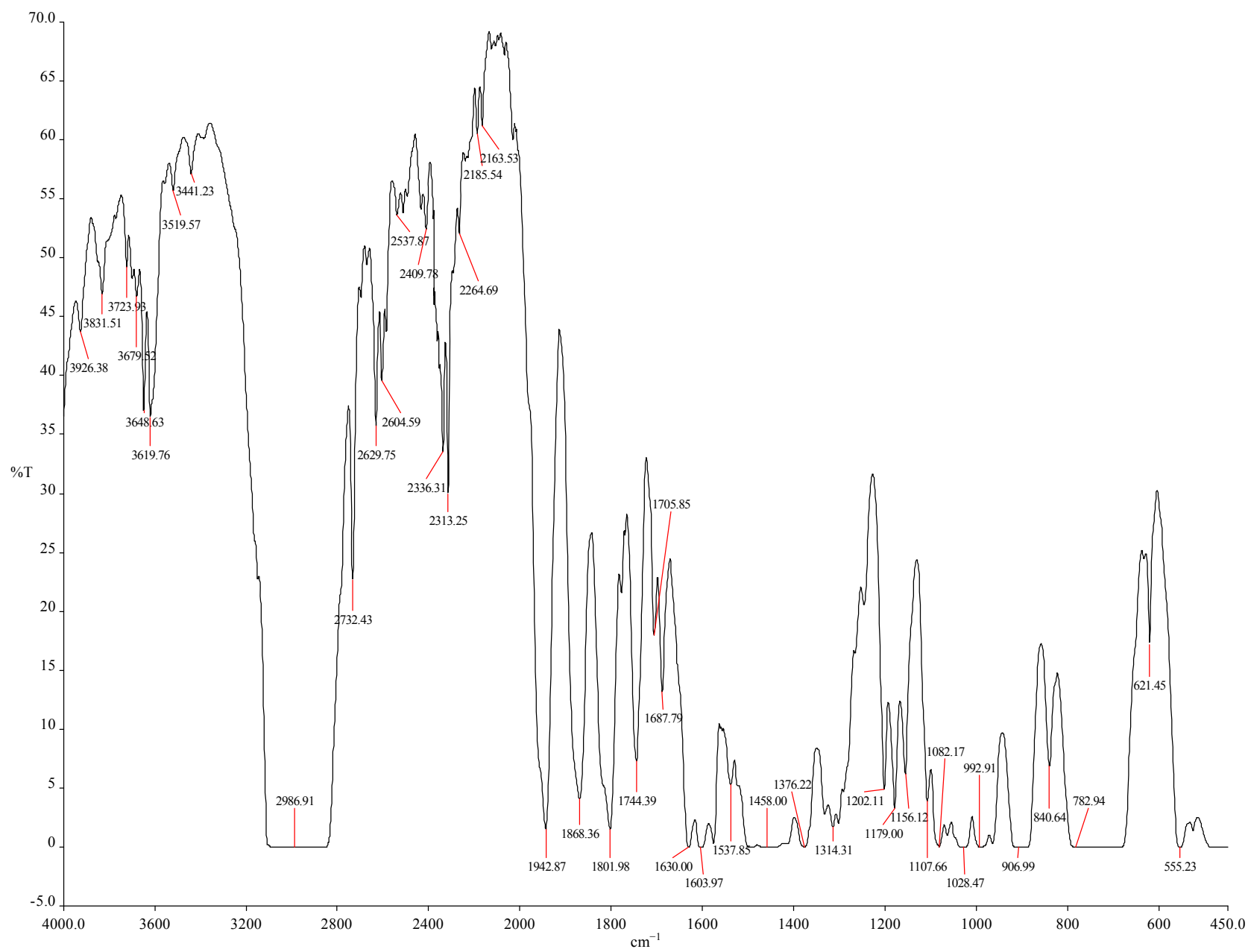

Figure 3. FT-IR spectrum of polystyrene waste plastic to aromatic hydrocarbon naphtha fuel.

Table 2. Polystyrene waste plastic to naphtha grade fuel functional group name.

\begin{tabular}{cccccc}
\hline Number of wave & $\begin{array}{c}\text { Wave number } \\
\left(\mathbf{c m}^{-1}\right)\end{array}$ & Functional group name & $\begin{array}{c}\text { Number of } \\
\text { wave }\end{array}$ & $\begin{array}{c}\text { Wave number } \\
\left(\mathbf{c m}^{-1}\right)\end{array}$ & $\begin{array}{c}\text { Functional group } \\
\text { name }\end{array}$ \\
\hline 4 & 3619.76 & Free OH (Sharp) & 17 & 1744.39 & Non-Conjugated \\
5 & 3519.57 & Intramolecular H Bonds (Sharp) & 18 & 1705.85 & Non-Conjugated \\
6 & 3441.23 & Intermolecular H Bonds (broad) & 19 & 1630.00 & Non-Conjugated \\
7 & 2986.91 & $\mathrm{C}-\mathrm{CH}_{3}$ & 20 & 1603.97 & Non-Conjugated \\
8 & 2732.43 & $\mathrm{C}-\mathrm{CH}$ & 22 & $\mathrm{CH}_{2}$ & $\mathrm{CH}_{3}$ \\
9 & 2185.54 & $\mathrm{C}-\mathrm{C}=-\mathrm{C}-\mathrm{C}=-\mathrm{CH}$ & 23 & 1458.00 & $\mathrm{Acetates}$ \\
10 & 2163.53 & $\mathrm{C}-\mathrm{C}=-\mathrm{C}-\mathrm{C}=-\mathrm{CH}$ & 26 & 1028.47 & $\mathrm{C}=\mathrm{CH}_{2}$ \\
15 & 1868.36 & Non-Conjugated & 27 & 992.91 & $-\mathrm{CH}_{2} \mathrm{CH}_{2}$ \\
\hline
\end{tabular}

little heavier fuel because temperature range was use for naphtha fractional fuel $110^{\circ} \mathrm{C}-125^{\circ} \mathrm{C}$ and hydrocarbon compound range also little bigger which is showed into GC/MS analysis. From analysis graph showed fuel boil- ing percentage was $11.55 \%$ at temperature $50^{\circ} \mathrm{C}$ and $150^{\circ} \mathrm{C}$ temperature showed $84.84 \%$ fuel was boiled. From this analysis calculated enthalpy value and fuel boiling point temperature. 


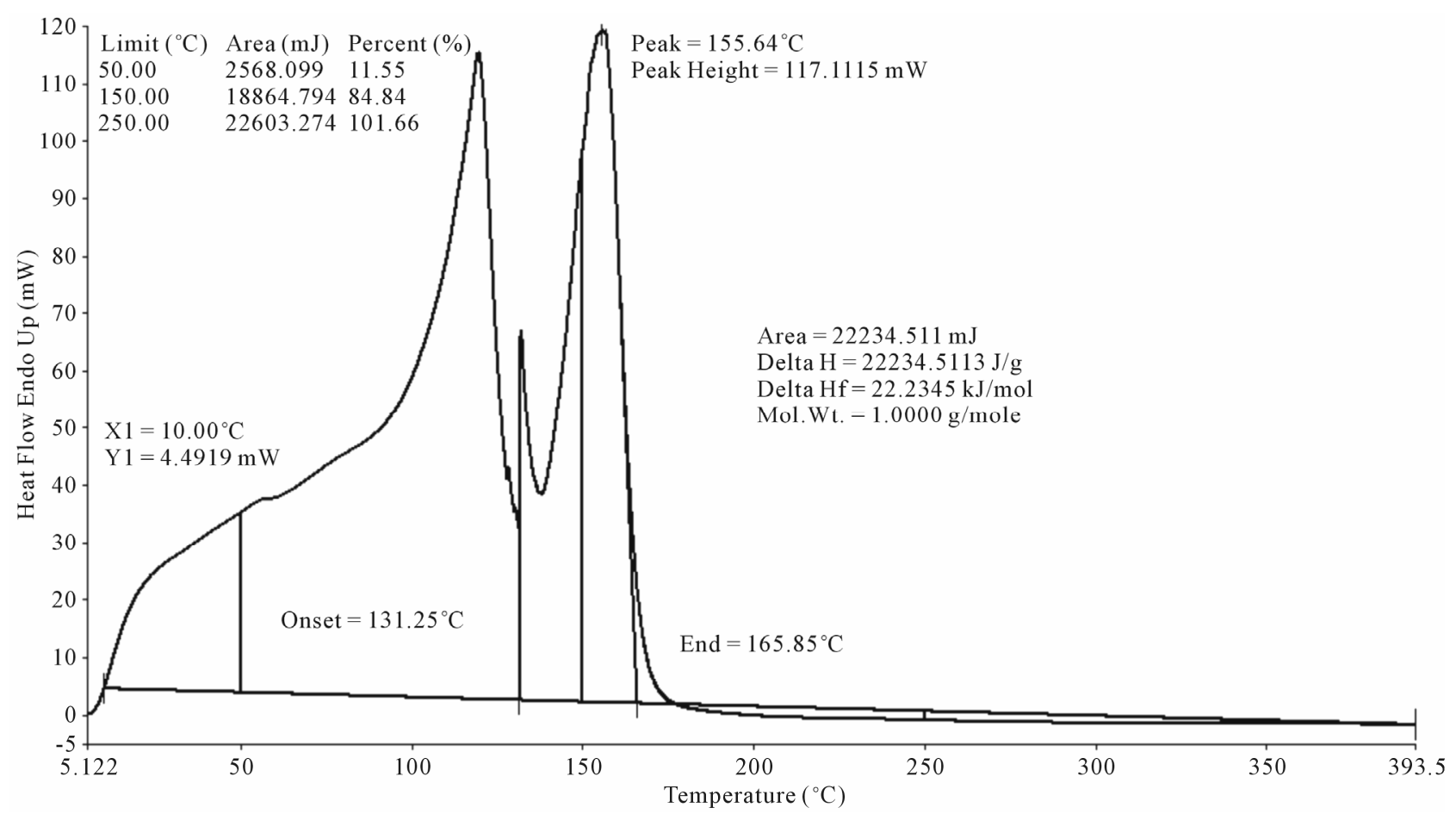

Figure 4. DSC graph of polystyrene waste plastic to aromatic hydrocarbon naphtha fuel.

\section{Conclusion}

Thermal degradation and fractional distillation process from polystyrene waste plastic to aromatic grade naphtha chemical product was by using GC/MS, FT-IR and DSC. Compositional analysis of Polystyrene (PS waste plasticderived thermolysis oil was accomplished at once by Gas chromatography and mass spectrometric analysis of whole spectrum of peaks for compound identification based on hydrocarbon level. By GC/MS analysis result showed hydrocarbon range $C_{7}$ to $C_{16}$ and most of the aromatic group related hydrocarbon compound such as Toluene, $\alpha$-Methylstyrene, Benzene, 1-ethyl-4-methyl-, Benzene, (1-methylbutyl)-, Benzene, (1-ethyl-2-propenyl)-, Benzene, cyclopentyl-, Naphthalene, 1,2,3,4-tetrahydro2-phenyl-, Benzene, 1,1'-(1,4-butanediyl)bis- and Benzene, 1,1'-(1-butenylidene)bis-. Polystyrene (PS) waste plastic has benzene group compound with long chain hydrocarbon. When heat applied for plastic melting purposed that time all compound bonding breakdown and from long chain hydrocarbon to short chain hydrocarbon compounds. Distilled PS waste plastic-derived thermolysis oil contained much more aromatics amounting to 60 $82 \mathrm{wt} \%$ of whole aromatic hydrocarbons than comercially available petroleum oil. This aromatic hydrocarbon composition was dependent on the composition of the feeding a plastic, this is not only the kind of plastics, but also the whole chemical composition including impurities. By using FT-IR analysis result showed compound band energy and it's reflect calorific value or functional group band energy and DSC analysis result showed enthalpy value and fuel boiling point temperature. PS waste plastic to produced aromatic chemical product could be use into chemical feedstock refinery.

\section{Acknowledgements}

The author acknowledges the support of Dr. Karin Kaufman, the founder and sole owner of Natural State Research, Inc. The authors also acknowledge the valuable contributions NSR laboratory team members during the preparation of this manuscript.

\section{REFERENCES}

[1] W. Kaminsky and I. J. N. Zorriqueta, "Catalytical and Thermal Pyrolysis of Polyolefins," Journal of Analytical and Applied Pyrolysis, Vol. 79, No. 1-2, 2007, pp. 368374. doi:10.1016/j.jaap.2006.11.005

[2] M. Predel and W. Kaminsky, "Pyrolysis of Mixed Polyolefins in a Fluidised-Bed Reactor and on a Pyro-GC/MS to Yield Aliphatic Waxes," Polymer Degradation and Stability, Vol. 70, No. 3, 2000, pp. 373-385. doi:10.1016/S0141-3910(00)00131-2

[3] R. Aguado, M. Olazar, M. J. San Jose, B. Gaisan and J. Bilbao, "Wax Formation in the Pyrolysis of Polyolefins in a Conical Spouted Bed Reactor," Energy Fuels, Vol. 16, No. 6, 2002, pp. 1429-1437. doi:10.1021/ef020043w

[4] A. Marcilla, M. I. Beltran and R. Navarro, "Study of the Deactivation Process of HZSM5 Zeolite during Polyethylene Pyrolysis," Applied Catalysis A: General, Vol. 57, 
No. 1, 2007, pp. 57-66.

[5] A. Marcilla, A. Gomez and S. Menargues, "TGA/FTIR Study of the Evolution of the Gases Evolved in the Catalytic Pyrolysis of Ethylene-Vinyl Acetate Copolymers. Comparison among Different Catalysts," Polymer Degradation and Stability, Vol. 89, No. 3, 2005, pp. 454-460. doi:10.1016/j.polymdegradstab.2005.01.024

[6] M. R. Hernandez, A. N. Garcia and A. Marcilla, "Catalytic Flash Pyrolysis of HDPE in a Fluidized Bed Reactor for Recovery of Fuel-Like Hydrocarbons," Journal of Analytical and Applied Pyrolysis, Vol.78, No. 2, 2007, pp. 272-281.

[7] A. Marcilla, A. Gomez-Siurana and D. Berenguer, "Study of the Early Deactivation in Pyrolysis of Polymers in the Presence of Catalysts," Journal of Analytical and Applied Pyrolysis, Vol. 79, No. 2, 2007, pp. 443-449. doi:10.1016/j.jaap.2007.02.002

[8] S. C. Cardona and A. Corma, "Tertiary Recycling of Polypropylene by Catalytic Cracking in a Semibatch Stirred Reactor: Use of Spent Equilibrium FCC Commercial Catalyst," Applied Catalysis B: Environmental, Vol. 25, No. 2-3, 2000, pp. 151-162. doi:10.1016/S0926-3373(99)00127-7

[9] S. Chaianansutcharit, R. Katsutath, A. Chaisuwan, T. Bhaskar, A. Nigo, A. Muto and Y. Sakata, "Catalytic Degradation of Polyolefins over Hexagonal Mesoporous Silica: Effect of Aluminum Addition," Journal of Analytical and Applied Pyrolysis, Vol. 80, No. 2, 2007, pp. 360-368. doi:10.1016/j.jaap.2007.04.009

[10] S. Ali, A. A. Garforth, D. H. Harris, D. J. Rawlence and Y. Uemichi, "Polymer Waste Recycling over 'Used' Catalysts," Catalysis Today, Vol. 75, No. 1-4, 2002, pp. 247255. doi:10.1016/S0920-5861(02)00076-7

[11] A. Marcilla, M. I. Beltran and R. Navarro, "Thermal and Catalytic Pyrolysis of Polyethylene over HZSM5 and HUSY Zeolites in a Batch Reactor under Dynamic Conditions," Applied Catalysis B: Environmental, Vol. 86, No. 1-2, 2008, pp. 78-86.

[12] J. Mertinkat, A. Kirsten, M. Predel and W. Kaminsky, "Cracking Catalysts Used as Fluidized Bed Material in the Hamburg Pyrolysis Process," Journal of Analytical and Applied Pyrolysis, Vol. 49, No. 1-2, 1999, pp. 87-95. doi:10.1016/S0165-2370(98)00103-X

[13] M. R. Hernandez, A. Gomez, A. N. Garcia, J. Agullo and A. Marcilla, "Effect of the Temperature in the Nature and Extension of the Primary and Secondary Reactions in the Thermal and HZSM-5 Catalytic Pyrolysis of HDPE," Applied Catalysis A: General, Vol. 317, No. 2, 2007, pp. 183-194.

[14] J. Scheirs and W. Kaminsky, "Feedstock Recycling and Pyrolysis of Waste Plastics,” Wiley, Chichester, 2006.

[15] J. M. Arandes, M. J. Azkoiti, I. Torre, M. Olazar and P. Castano, "Effect of HZSM-5 Catalyst Addition on the Cracking of Polyolefin Pyrolysis Waxes under FCC Conditions," Chemical Engineering Journal, Vol. 17, 2007, pp. 17-26.

[16] J. Aguado and D. Serrano, "Feedstock Recycling of Plastic Wastes," Royal Society of Chemistry, Cambridge, 1999.
[17] A. Marcilla, M. I. Beltran and R. Navarro, "Evolution with the Temperature of the Compounds Obtained in the Catalytic Pyrolysis of Polyethylene over HUSY," Industrial \& Engineering Chemistry Research, Vol. 47, No. 18, 2008, pp. 6896-6903. doi:10.1021/ie800520u

[18] M. W. Rosegrant, "Biofuels and Grain Prices: Impacts and Policy Responses," International Food Policy Research Institute, Washington DC, 2008.

[19] W. L. Yoon, J. S. Park, H. Jung, H. T. Lee and D. K. Lee, "Optimization of Pyrolytic Coprocessing of Waste Plastics and Waste Motor Oil into Fuel Oils Using Statistical Pentagonal Experimental Design," Fuel, Vol. 78, No.7, 1999, pp. 809-813. doi:10.1016/S0016-2361(98)00207-5

[20] N. Miskolczi, A. Angyal, L. Bartha and I. Valkai, "Fuels by Pyrolysis of Waste Plastics from Agricultural and Packaging Sectors in a Pilot Scale Reactor," Fuel Processing Technology, Vol. 90, No. 7-8, 2009, pp. 1032-1040. doi:10.1016/j.fuproc.2009.04.019

[21] S. M. Al-Salem, P. Lettieri and J. Baeyens, "Recycling and Recovery Routes of Plastic Solid Waste (PSW): A Review," Waste Management, Vol. 29, No. 10, 2009, pp. 2625-2643. doi:10.1016/j.wasman.2009.06.004

[22] S. M. Al-Salem, P. Lettieri and J. Baeyens, "The ValoriZation of Plastic Solid Waste (PSW) by Primary to Quaternary Routes: From Reuse to Energy and Chemicals," Progress in Energy and Combustion Science, Vol. 36, No. 1, 2010, pp. 193-129.

[23] S. J. Miller, "Conversion of Waste Plastic to Lubricating Base Oil," Energy Fuels, Vol. 19, No. 4, 2005, pp. 15801586. doi:10.1021/ef049696y

[24] K. Smolders and J. Baeyens, "Thermal Degradation of PMMA in Fluidized Beds," Waste Manage, Vol. 24, No. 8, 2004, pp. 849-857. doi:10.1016/j.wasman.2004.06.002

[25] M. P. Aznar, M. A. Caballero, J. A. Sancho and E. France's, "Plastic Waste Elimination by Co-Gasification with Coal and Biomass Influidized Bed with Air in Pilot Plant," Fuel Processing Technology, Vol. 87, No. 5, 2006, pp. 409-420. doi:10.1016/j.fuproc.2005.09.006

[26] A. Demirbas, "Pyrolysis of Municipal Plastic Wastes for Recovery of Gasoline-Range Hydrocarbons," Journal of Analytical and Applied Pyrolysis, Vol. 72, No. 1, 2004, pp. 97-102. doi:10.1016/j.jaap.2004.03.001

[27] E. A. Williams and P. T. Williams, "Analysis of Products Derived from the Fast Pyrolysis of Plastic Waste," Journal of Analytical and Applied Pyrolysis, Vol. 40-41, 1997, pp. 347-363. doi:10.1016/S0165-2370(97)00048-X

[28] J. Ahrenfeldt, "Characterization of Biomass Producer Gas as Fuel for Stationary Gas Engines in Combined Heat and Power Production," Ph.D. Thesis, Technical University of Denmark, Lyngby, 2007.

[29] T. Bhaskar, M. A. Uddin, A. Muto, Y. Sakata, Y. Omura, K. Kimura and Y. Kawakami, "Recycling of Waste Lubricant Oil into Chemical Feedstock or Fuel Oil over Supported Iron Oxide Catalysts," Fuel, Vol. 83, No. 1, 2004, pp. 9-15. doi:10.1016/S0016-2361(03)00216-3

[30] A. Demirbas, "Biodiesel: A Realistic Fuel Alternative for Diesel Engines," Springer, London, 2008.

[31] Y. S. Kim, Y. S. Kim, K. M. Kim, S. U. Jeong and S. H. 
Kim, "Thermal Decomposition Kinetics of Polymeric Wastes Using a Nonisothermal Thermogravimetric Method," Journal of Industrial and Engineering Chemistry, Vol. 9, No. 3, 2003, pp. 219-224.

[32] S. Kim and S. Kim, "Pyrolysis Characterixtics of Polystyrene and Polypropylene in a Stirred Batch Reactor," Chemical Engineering Journal, Vol. 98, No. 1-2, 2004, pp. 53-60. doi:10.1016/S1385-8947(03)00184-0

[33] S. Lovett, F. Berruti and L. A. Behie, "Ultrapyrolytic Upgrading of Plastic Wastes and Plastics/Heavy Oil Mixtures to Valuable Light Gas Products," Industrial \& Engineering Chemistry Research, Vol. 36, No. 11, 1997, pp. 4436-4444. doi:10.1021/ie970109o

[34] H. Bockhorn, A. Hornung, U. Hornung and D. Schawaller, "Kinetic Study on the Thermal Degradation of Polypropylene and Polyethylene," Journal of Analytical and Applied Pyrolysis, Vol. 48, No. 2, 1999, pp. 93-109. doi:10.1016/S0165-2370(98)00131-4

[35] Y. S. Kim, Y. S. Kim and S. H. Kim, "Investigation of Thermodynamic Parameters in the Thermal Decomposition of Plastic Waste-Waste Lube Oil Compounds," Envi- ronmental Science \& Technology, Vol. 44, No. 13, 2010, pp. 5313-5317. doi:10.1021/es101163e

[36] REN21, "Renewables 2011: Global Status Report," 2011. http://www.ren21.net/Portals/97/documents/GSR/GSR20 11_Master18.pdf

[37] W. Moomaw and F. Yamba, "Renewable Energy and Climate Change," 2012. http://srren.ipcc-wg3.de/report/IPCC_SRREN_Ch01.pdf

[38] A. Oberheitmann, "Development of a Low Carbon Economy in Wuxi City," American Journal of Climate Change, Vol. 1, No. 2, 2012, pp. 64-103. doi:10.4236/ajcc.2012.12007

[39] Z. Yang, "The Right to Carbon Emission: A New Right to Development," American Journal of Climate Change, Vol. 1, No. 2, 2012, pp. 108-116. doi:10.4236/ajcc.2012.12009

[40] P. Söderholm, "Modeling the Economic Costs of Climate Policy: An Overview," American Journal of Climate Change, Vol. 1, No. 1, 2012, pp. 14-32.

doi:10.4236/ajcc.2012.11002 